\title{
BIM and PLM associations in current literature
}

\author{
Giovanna Mangialardi ${ }^{1}$, Carla Di Biccari ${ }^{1}$, Claudio Pascarelli ${ }^{1}$, \\ Mariangela Lazoi ${ }^{1}$, Angelo Corallo ${ }^{1}$ \\ Department of Engineering for Innovation, University of Salento, Lecce, Italy \\ giovanna.mangialardi@unisalento.it \\ carla.dibiccari@unisalento.it \\ claudio.pascarelli@unisalento.it \\ mariangela.lazoi@unisalento.it \\ angelo.corallo@unisalento.it
}

\begin{abstract}
Building Information Modeling (BIM) and Product Lifecycle Management (PLM) have been associated many times in recent literature and the possibilities for their integration or to be mutually used as a source of lesson learned has been envisaged. The paper proposes to analyze, through a systematic literature review approach, the existing state of art of previous studies that has already examined relations between BIM and PLM. The main objective of the paper is to understand the real nature of BIM-PLM association for better directing future research developments.
\end{abstract}

Keywords: BIM, PLM, BLM, review

\section{Introduction}

Assuring efficient and effective management, collaboration and sharing processes is fundamental to ensure the right actions sequences necessary to achieve a good project or a good product, avoiding errors, losses of time and compartmentalized situations where professionals assumed separate and strictly defined roles with disciplinebased responsibilities. This is valid both for a complex product in the Manufacturing Industry and for a complex building in the Architecture, Engineering and Construction (AEC) one. In the automotive and aerospace industries the development process management, and the storage and control of product related data, occurred since the late '80s, first with the PDM (Product Data Management) [1] that was later included in the PLM paradigm, emerged in 2001 [2]. The PLM for Corallo et al. [3] "is a strategic business approach that supports all the phases of product lifecycle, from concept to disposal, providing a unique and timed product data source. Integrating people, processes, and technologies and assuring information consistency, traceability, and long term archiving, PLM enables organizations to collaborate within and across the extended enterprise". Therefore, the PLM, supported by Information Technologies, sets up highly complex production and management tasks. In the construction sector, this systematization of processes, people and resources, is known in literature as 
Building Information Modeling. This term became popular only in 2002 [4], thanks to J. Laiserin, even if C. Eastman starts talking about it in the late '70s [5]. Today it is diffusely recognized "as set of interacting policies, processes and technologies generating a methodology to manage the essential building design and project data in digital format throughout the building's life cycle" [6] [7]. Theoretically, BIM should cover all the phases of a construction life cycle but at the moment, it is mainly focus on the design phase. Furthermore, its current state of development shows that many others researches can and must be done in view of the benefits deriving from its adoption [8].

Many publications cited the terms BIM and PLM contextually for different reasons, sometimes assuming they are two sides of the same coin, sometimes that they share similarities and sometimes that one is part of the other. Therefore, as a preliminary study of a broader project focused on the realization of a BLMS (Building Lifecycle Management System), this paper aims to analyze studies discussing about BIM and PLM in the same context in order to fix the current authors' points of view and addressing future research. The research wants to clarify scientific literature position about the nature of the association between BIM and PLM concepts through a systematic literature review approach of papers that have already examined this relation (i.e. as definition, as industries where they are adopted, as types and reasons of the association).

The next section of the paper describes the research method and, in particular, the papers selection and assessment. In sections 3, 4, 5 and 6, definitions, industries, type of associations and benefits, based on the literature review are respectively, explained. A final section of conclusion and further developments ends the paper.

\section{Research method}

This study uses a literature review process to compare and fully understand the current state of association between Building Information Modeling and Product Lifecycle Management, in order to reach a shared interpretation and better direct future research developments.

Between the systematic and narrative literature review approaches [9], the choice has been in favour of the systematic literature review that allows to reach the following objectives: establish the nature of the relationship between BIM and PLM, comparing their definitions and meanings, their respective industries, the degree of association and the potential benefits deriving from their adoption, to identify fields to focus future research. The key characteristics of the systematic review method adopted in the present research are: planning the review on the basis of keywords and search terms with a replicable and defined search strategy. The literature review cannot be considered exhaustive but represent a significant vision of a current research interest at international level. 


\subsection{Selection and assessment process}

The papers search was carried out through three important indexed electronic scientific databases: Web of Science (www.webofknowledge.com), Scopus (www.scopus.com) and Scholar (scholar.google.it). The research took place until May 2017. The criteria for searching was four combination of words: "PLM" and "BIM"; "PLM" and "Building Information Modeling"; "Product Lifecycle Management" and "BIM"; "Product Lifecycle Management" and "Building Information Modeling". The search in Web on Science, conducted into "Title" and "Topic", returned 10 articles, instead, the search in Scopus, conducted into "Title", "Keywords" and "Abstract", found 23 articles ( 10 of them were the same of Web of Science), two of which were not available for download. The search in Scholar, conducted into "Advanced Research" on "Article Title", from 2007 to 2017, returned 13 articles, (the same reported by the other databases), five of which were not taken in consideration due to the language (Chinese, Russian). As a result, a total of 23 scientific papers were identified.

The first step of the reviewing process is the preparation of a matrix to record authors notes about each article, providing a standard structure. In detail, the 23 papers were evaluated in ascending chronological order using a structured form with 12 columns including: title, publication year, source, authors with affiliations, abstract, keywords, document type, study focus, definitions of BIM/PLM, industrial issues, degree of association, benefits of association.

The second step of the research method, is the realization of a summary, in a critical way, about the significant data identified for each paper. Contents are compared and discussed. The following points are analyzed: the definition of BIM/PLM, a list of industrial features in the adoption of BIM or PLM, the type of association between BIM and PLM, and, finally, the benefits highlighting in the treatment of BIM and PLM in the same context. The results of this comparative review are reported in the following paragraphs.

\section{Definitions}

Before the development of his research, almost each author of the analyzed papers, states which definition of BIM and PLM refers to. These definitions can be considered as a first hint of the nature of the association observed later. Some nouns (i.e. approach, IT system, process) and attributes (i.e. object-oriented, model-driven, inclusive synonyms) were found to be very common across definitions. Table 1 classifies the selected papers both according to nouns used in the definition of BIM and/or PLM(i.e. approach, IT system, process, and their synonyms) and the attributes (i.e. object-oriented, model-driven and their synonyms).

Table 1. Summary of BIM and PLM definition classification

\begin{tabular}{|l|l|l|l|l|l|}
\hline \multirow{2}{*}{} & \multicolumn{2}{|c|}{ Nouns } & \multicolumn{2}{|c|}{ Attributes } \\
\cline { 2 - 5 } & Approach & IT system & Process & Object-oriented & $\begin{array}{l}\text { Model Driven, } \\
\text { Model }\end{array}$ \\
\hline
\end{tabular}




\begin{tabular}{|c|c|c|c|c|c|}
\hline BIM & $\begin{array}{l}\text { [10], [11], [12], } \\
{[13],[14],[15],} \\
{[16][38],[39]} \\
{[40]}\end{array}$ & $\begin{array}{l}\text { [11], [12], [16], [17], [18], } \\
{[19],[20],[21],[22],[23],} \\
{[24],[25],[39]}\end{array}$ & {$[11],[26]$} & $\begin{array}{l}\text { [10], [12], [15], } \\
{[16],[17],[19],} \\
{[22],[23],[24],} \\
{[26],[27]}\end{array}$ & $\begin{array}{l}\text { [11], [13], [15], } \\
{[16],[21],[22],} \\
{[28],[29],[40]}\end{array}$ \\
\hline PLM & $\begin{array}{l}{[10],[11],[12],} \\
{[22],[26],[38],} \\
{[39]}\end{array}$ & $\begin{array}{l}\text { [10], [11], [13], [17], [18], } \\
{[20],[21],[22],[25],[26],} \\
{[27],[28],[29]}\end{array}$ & [11], [26] & & [11] \\
\hline
\end{tabular}

BIM and PLM have been described by means of one or more definitions, depending on the aim of the research. Some papers used all the three nouns at once. This can be a hint of a multifaceted nature of both concept. The most numerous group seems to be that of authors who considered BIM and/or PLM as an IT system. On the other hand, PLM has never been described through the attribute 'object-oriented'. When they are seen as IT systems, papers listed even the main functionalities of PLM systems ([13], [18], [21], [22], [26]) and of BIM systems; [26] also produces a scheme to easily visualize overlapping functionalities of the two systems.

\section{$4 \quad$ Industries in the reviewed papers}

All the papers refer to AEC Industry in general as typical sector for BIM application. [27] focuses specifically on civil structures and [25] focuses on modular building construction as an industrialized sector. The papers dealing with PLM, refer to Complex Manufacturing Sectors and, in detail, to the Automotive and Aerospace Industry. [19] and [24] refer to the Shipbuilding Industry as a sector with an incomplete adoption of PLM that would benefit from BIM. [10], [17] and [18] expose cases of AEC companies that have already adopted PLM in their organizational management.

Almost every paper included in this review highlights that processes, projects and products are "complex" in both sectors, but for [11], [12] and [18] AEC and manufacturing industries have specific structural, background and traditional characteristics, different technology applications, methods, scope of business and tools.

The AEC industry, whose supply chain management is more project-based, is characterized by small or medium sized companies with innovation deficit and small economic resources to invest in expensive and integrated technologies. Indeed, the level of technology adoption ranges from low to medium with consequent lack of process commonality, standardization and integration between IT processes and software. The industries are highly fragmented and remain rooted in local context. The projects are different every time.

Conversely, Manufacturing companies, whose supply chain management is product-based, are larger, more globalized and consolidated. These aspects facilitate greater investments in innovative digital applications and guarantee long standing and collaborative relationships with customers. Generally, the Manufacturing industry is characterized by higher levels of IT integration and adoption of PLM system. Not all manufacturing companies have a holistic view of the whole product lifecycle but their structure, IT equipment and more mature mentalities help this transition. Accordingly, six different characteristics of the AEC industry for BIM application and of the Manufacturing one for PLM application were identified and synthesized in Table 2. 
Table 2. Industry characteristics

\begin{tabular}{|c|c|c|c|c|c|c|}
\hline \multirow[b]{2}{*}{ Sector Type } & \multicolumn{6}{|c|}{ Characteristic } \\
\hline & $\begin{array}{l}\text { Firms } \\
\text { Dimen- } \\
\text { sion } \\
\end{array}$ & $\begin{array}{l}\text { Data } \\
\text { management } \\
\text { and tool } \\
\end{array}$ & $\begin{array}{l}\text { IT } \\
\text { adoption }\end{array}$ & $\begin{array}{l}\text { Industry } \\
\text { organiza- } \\
\text { tion } \\
\end{array}$ & $\begin{array}{l}\text { Product } \\
\text { Type }\end{array}$ & $\begin{array}{l}\text { Supply chain } \\
\text { management and } \\
\text { industry structure }\end{array}$ \\
\hline \multicolumn{7}{|c|}{ BIM } \\
\hline $\begin{array}{l}\text { AEC } \\
\text { Industry } \\
\text { (all papers) } \\
\text { Shipbuilding } \\
\text { Industry } \\
{[19],[24]}\end{array}$ & $\begin{array}{l}\text { Small and } \\
\text { Medium } \\
{[10],[17] \text {, }} \\
{[18],[38]}\end{array}$ & $\begin{array}{l}\text { Largely } \\
\text { separate } \\
\text { application } \\
\text { modules. } \\
\text { 3D CAD, } \\
\text { CAM,CAE, } \\
\text { 4D - 5D } \\
\text { BIM. } \\
{[10],[21]}\end{array}$ & $\begin{array}{l}\text { low and } \\
\text { medium } \\
{[10],} \\
{[11],[18] \text {, }} \\
{[38],[40]}\end{array}$ & 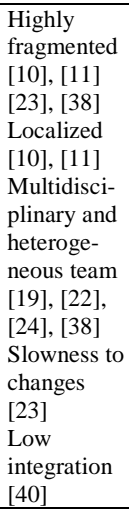 & 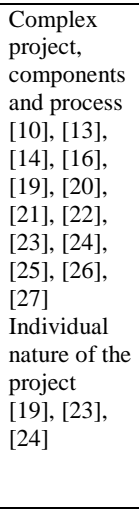 & $\begin{array}{l}\text { Project Based } \\
{[10],[17],[18],[23]} \\
\text { High variation in } \\
\text { project structures and } \\
\text { delivery methods } \\
\text { [18] } \\
\text { Short Term and more } \\
\text { isolated relationships } \\
\text { with client } \\
{[10],[38]} \\
\text { Lack of process } \\
\text { commonality, } \\
\text { standardization and } \\
\text { integration } \\
{[10],[11],[23],[38],} \\
{[39]}\end{array}$ \\
\hline \multicolumn{7}{|c|}{ PLM } \\
\hline $\begin{array}{l}\text { Complex } \\
\text { Manufactur- } \\
\text { ing Sectors } \\
\text { and in detail } \\
\text { Automotive } \\
\text { and } \\
\text { Aerospace } \\
\text { Industry } \\
\text { (all papers) } \\
\text { Shipbuilding } \\
\text { Industry } \\
\text { [19], [24] } \\
\text { AEC } \\
\text { Industry } \\
\text { [10], [17], } \\
\text { [18] }\end{array}$ & $\begin{array}{l}\text { Big, } \\
\text { globalized } \\
\text { and } \\
\text { consoli- } \\
\text { dated } \\
{[10],[11],} \\
{[38]}\end{array}$ & $\begin{array}{l}\text { Higher } \\
\text { Levels of } \\
\text { integration. } \\
\text { PLM [40] } \\
\text { application } \\
\text { modules, } \\
\text { PDM, 3D } \\
\text { CAD,CAM, } \\
\text { CAE. Infor- } \\
\text { mation } \\
\text { modeling } \\
\text { architectures, } \\
\text { development } \\
\text { toolkits, } \\
\text { business app } \\
\text { [21], [10] }\end{array}$ & $\begin{array}{l}\text { long } \\
\text { experi- } \\
\text { enced of } \\
\text { PLM and } \\
\text { ERP use, } \\
\text { but with } \\
\text { different } \\
\text { levels of } \\
\text { adoption } \\
\text { [10], [12], } \\
\text { [17], [18], } \\
\text { [21], [23] }\end{array}$ & $\begin{array}{l}\text { Partially } \\
\text { integrated } \\
\text { "islands of } \\
\text { infor- } \\
\text { mation" } \\
{[11]} \\
\text { Globalized } \\
\text { and consol- } \\
\text { idated } \\
{[10]}\end{array}$ & $\begin{array}{l}\text { Complex } \\
\text { product } \\
{[10],[13],} \\
{[18],[20],} \\
{[21],[23],} \\
{[24],[25],} \\
{[26]}\end{array}$ & $\begin{array}{l}\text { Product based } \\
{[10],[11]} \\
\text { Long Standing and } \\
\text { collaborative } \\
\text { relationships } \\
\text { with client } \\
{[10],[38]} \\
\text { Lack of a holistic } \\
\text { view of users of } \\
\text { information } \\
\text { [11] } \\
\text { Engineering methods. } \\
\text { Support decision- } \\
\text { making from whole } \\
\text { life cycle perspective } \\
{[10],[38]}\end{array}$ \\
\hline
\end{tabular}

Despite of several different current characteristics identified, almost each paper includes potential future similarities for companies adopting BIM and/or PLM. In detail, for both industries, data governance, information management, storage and distribution, are important for the whole building/product lifecycle, together with the new competencies and digital skills required [10], [11], [12], [21]. For example, for [21] the "Advanced use and management of digital product data that shortens time-tomarket, gives tools for product information distribution and changes management, better and reliable tools for customer requirements", and for [10] "collaborative ways of working, procurement methods, and process planning" are advantages desired in both construction and mechanical engineering industries, although there are structural barriers like the lack of vertical and horizontal integration. 


\section{$5 \quad$ Types of association}

Since in the sample of analyzed papers, BIM and PLM are often put in reference, in this section, the aim is to describe the nature of this association. The analysis identified four types of BIM-PLM association to which the papers can be led back: sharing similarities, being different entities, being complementary entities, being comparable.

When BIM-PLM share similarities, whether defined as systems, approaches or models, they have something in common, for example as in [11] "relative to their approach to data sharing, project management, organization of teams around deliverables and timelines and object based visualization activities." [40] affirms that they share similarities but "differ for technical and organizational integration".

Papers that treat BIM and PLM as different entities, are those like [17] that keeps them as two worlds apart, considering BIM as an enabler to link PLM to ERP, or papers that conceive them for different functions as in [18] and [29] where PLM is a unifying platform for data produced by BIM-based authoring tools, or in [14] where BIM integrated with 3D capturing processes can move towards "a special kind of Product Life cycle Management (PLM), Building Life cycle Management (BLM)". Similarly in [21] BIM's function is producing digital product data and information (authoring tools like CAD, CAM, CAT) and PLMs' is handling digital product information. In this group there is also [15] that sees BIM as an approach for design and analysis that offers a static view of the building, PLM, instead can simulate the management and is associated with the dynamic view of the building in time.

PLM and BIM were "complementary" when together they were said capable of creating a whole complete new entity. In [22] BIM and PLM together create something different, i.e. BLM. In [26], instead, they are complementary systems to fully implement Lean methodology in Construction.

On the other hand, four papers state they are fully comparable; for example [27] says that they are "comparable virtual models" and [20] considers them as two "collaborative applications". In [23] the type of association is not clearly stated, even if PLM is among paper keywords, it appears only in a figure caption "Figure 5: Commissioning/as-built BIM must keep PLM in mind" with no further explanation.

Table 3. Types of BIM/PLM association

\begin{tabular}{|l|l|l|l|}
\hline \multicolumn{1}{|c|}{$\begin{array}{c}\text { Share } \\
\text { Similarities }\end{array}$} & \multicolumn{1}{|c|}{ Different } & Complementary & \multicolumn{1}{c|}{ Comparable } \\
\hline$[10],[11],[12],[13]$, & {$[14],[15],[16],[17]$,} & {$[22],[26],[40]$} & {$[20] \ldots$ collaborative applications } \\
{$[19],[38],[39],[40]$} & {$[18],[21],[29]$} & & $\begin{array}{l}{[25] \ldots \text { information management frameworks }} \\
{[27] \ldots \text { comparable virtual models }} \\
\end{array}$ \\
& & & {$[28] \ldots$ BIM is an immature PLM } \\
\hline
\end{tabular}

Looking at the association purpose, the reviewed papers have been gathered according to the four most common reasons: learning lessons already known in other industries where the other system has been previously applied and more knowledge has been matured, suggesting the integration of PLM functionalities to BIM, loosely integrating PLM systems and BIM, adopt some BIM aspects into PLM (Table 4). 
Table 4. BIM/PLM scope of association

\begin{tabular}{|l|l|l|l|}
\hline $\begin{array}{c}\text { Lesson learned in } \\
\text { other industries }\end{array}$ & $\begin{array}{c}\text { BIM Inherits } \\
\text { functionalities from PLM }\end{array}$ & $\begin{array}{c}\text { PLM learns from } \\
\text { BIM }\end{array}$ & $\begin{array}{c}\text { PLM system loosely } \\
\text { integrated with BIM }\end{array}$ \\
\hline$[10],[11],[12],[17]$, & {$[13],[14],[15],[16]$,} & {$[19]$} & \\
{$\left[\begin{array}{l}{[18],[19],[22],[24],} \\
{[27],[28],[38],[40]}\end{array}\right.$} & {$[22],[25],[26],[29],[38],[39]$} & & {$[18],[21]$} \\
\hline
\end{tabular}

In general, BIM and PLM have been associated in order to transfer functionalities and characteristics from PLM to BIM, or from the manufacturing world where PLM was born to the construction, as also noticed in [10]: "the motivations of previous PLM-BIM comparisons have typically surrounded the transfer of PLM functions and industry characteristics from the complex manufacturing industries to the construction industry." In many papers, BIM is considered as incomplete, it especially seems to lack collaboration and facility management functionalities [16], [21] and [27]. Furthermore, [16] also points out that tools alone are not sufficient for BIM implementation but " drastic changes in term of work practices, staff skills, relations with client and participants of project implementation team as well as contractual arrangements are required". Only [20] suggests that collaboration should be enabled in both systems. In [14] [16], [22], [26] and [40] the integration of BIM with PLM functionalities can lead to Building Lifecycle Management (BLM) considering BLM as the PLM version for the construction industry. Similarly, [29] introduces Construction Product Lifecycle Management (CPLM), a term for a PLM that is specific for the construction industry. In an early article [15] this concept is even called 4D PLM. Moreover [14], [15], [19], [20], [21], [24], and [27] focus more on the authoring or 3D modeling aspects of both BIM and PLM in order to clarify the type of Association of BIM/PLM, by defining the similarities, differences, complementarity and the comparison. Interestingly [25] compares BIM to what Product Information Modeling (PIM) is in manufacturing: a structure that represents the data model for a specific product in manufacturing that can enable the interoperability of PLM [30].

\section{Benefits from BIM/PLM integration}

According to the analyzed papers, a classification based on the benefits derived from BIM and PLM integration is provided. In general, it emerges that the construction industry stands to benefit more in learning from PLM application and from the professional practice in the industrial sector ([11], [10], [18] ,[25], [38] and [40]). These researches show that the main aspects missing in AEC industry could benefit by the great experience of PLM application in manufacturing industry in sharing of information at various stages of the life cycle. In particular, the AEC facility management needs horizontal integration of several disparate systems, management of business workflow, using a shared database for all the phases.

For [10] "the construction industry is still in the early phases of BIM adoption and therefore stands to benefit most in learning from the experiences of manufacturing industries". Other researches (e.g. [10], [14], [15], [17], [21], [22], [26], [27] and [29]), try to integrate the two systems, because they are viewed as complementary. In 
detail, while [17] integrates BIM to link PLM with ERP and [38] cites BOM and Product structure as the missing links to fully exploit BIM; the others researches focus their attention on Project management systems and suggest to apply their functionalities for a better management of digital product data in all the phases of the construction process, including facility management. All take the benefits of the management process from PLM to BIM methodology.

Benefits are generally always similar, as it can be seen in Table 5, and they are focused on the Construction Industry where BIM is actually, in a phase of development and can benefits from PLM that is a more mature topic. The major advantages are: the increase of productivity, more cost efficient and sustainable manufacturing and production, optimization of design, minimize production waste, manage supply chain, standardize components of products and manage product changes and adoptions.

Table 5. Advantages of the comparison

\begin{tabular}{|c|c|c|c|}
\hline & \multicolumn{3}{|c|}{ Advantages } \\
\hline & $\begin{array}{c}\text { Kind of } \\
\text { Integration }\end{array}$ & $\begin{array}{c}\text { Capabilities and } \\
\text { Functionalities Involved }\end{array}$ & Kind of Benefit \\
\hline $\begin{array}{l}\text { [10], } \\
{[11],} \\
{[18],} \\
{[25],[38],} \\
{[40]}\end{array}$ & $\begin{array}{l}\text { Construction } \\
\text { Industry learns } \\
\text { from case } \\
\text { studies of PLM } \\
\text { and } \\
\text { professional } \\
\text { practice. } \\
\text { Lesson Learned } \\
\text { from PLM. } \\
\text { Construction } \\
\text { Industry uses } \\
\text { PLM system. } \\
\text { Insight in } \\
\text { closed loop } \\
\text { PLM research } \\
\text { and practices }\end{array}$ & $\begin{array}{l}\text { New activities, } \\
\text { roles/responsibilities, } \\
\text { knowledge competencies, } \\
\text { and supply chain relation- } \\
\text { ships. } \\
\text { Horizontal integration of } \\
\text { several disparate systems. } \\
\text { Business workflow. } \\
\text { Integration of existing PLM } \\
\text { platforms with BIM servers. } \\
\text { Comprehensive information } \\
\text { consolidation with business } \\
\text { intelligence tools. } \\
\text { Change management } \\
\text { features of PLM solutions. } \\
\text { Using a shared database. } \\
\text { Create a hybrid system } \\
\text { BIM-IoT-PLM }\end{array}$ & $\begin{array}{l}\text { Addressing shortcomings in collaborative design in } \\
\text { the AEC industry and enhance project performance. } \\
\text { Facilitating the capturing and consolidating infor- } \\
\text { mation of the current and past projects as well as } \\
\text { resources and strategic goals of an enterprise. } \\
\text { Enhancing efficient decision-making. } \\
\text { Promoting better use of resources and support agile } \\
\text { problem-solving. } \\
\text { Facilitating the uncovering, use and reuse of best } \\
\text { practices in design, requirements } \\
\text { management and project workflows. } \\
\text { Tracking design, fabrication and construction chang- } \\
\text { es in projects and ensuring consistency of working } \\
\text { information by different project entities. } \\
\text { Reduction of the ownership cost. } \\
\text { Increase productivity, optimize design, minimize } \\
\text { waste, manage supply chain, standardize components } \\
\text { of products and manage product changes } \\
\text { Closed loop BLM }\end{array}$ \\
\hline$[17],[38]$ & $\begin{array}{l}\text { Integrating BIM } \\
\text { with PLM and } \\
\text { ERP }\end{array}$ & $\begin{array}{l}\text { Software environment, } \\
\text { Integration of the infor- } \\
\text { mation system, BOM , } \\
\text { product structure }\end{array}$ & $\begin{array}{l}\text { Be more transaction-oriented, standardization, } \\
\text { increased connectivity }\end{array}$ \\
\hline $\begin{array}{l}{[10],[13],} \\
[14], 15], \\
[21], 22], \\
{[26],[27],} \\
{[28],[29],}\end{array}$ & $\begin{array}{l}\text { BIM and PLM } \\
\text { combined }\end{array}$ & $\begin{array}{l}\text { Merge functionalities. } \\
\text { Facility/project manage- } \\
\text { ment. PDM. } \\
\text { Lean features } \\
\text { BIM should become a } \\
\text { mature PLM or an integrat- } \\
\text { ed part of it. }\end{array}$ & $\begin{array}{l}\text { More cost efficient and sustainable manufacturing } \\
\text { and production. } \\
\text { Capacity of PLM system to unify and control various } \\
\text { tasks and steps of the construction industry. } \\
\text { PLM simulates project management, calculating the } \\
\text { precise resource demand on a 3D model, to deter- } \\
\text { mine Gantt and to assess effectively alternatives. }\end{array}$ \\
\hline
\end{tabular}

\section{$7 \quad$ Findings}

Comparing, learning from one another, looking for similarities and differences are not new concepts when it comes to BIM and PLM. Authors believe these are interest- 
ing current fields of research and of the twenty-three papers reviewed, many have been published in 2016, demonstrating the relevance of this topic.

Starting from definitions (Table 1), even if it is not uncommon that an author refers to both BIM and PLM as "approaches", IT system is the most spread noun to define them. This could mean that even if a strategy or a methodology lies behind BIM and PLM, without information technology the implementation would be difficult, if not impossible. Most papers use more than one of the nouns at the same time to define BIM and PLM, proving their multi-faceted nature. On the other side, "ObjectOriented" is an exclusive attribute of BIM. The parallel with Object Oriented Programming is intuitive and also found in [31] and [32].

The analysis of the respective industries highlights the current transition phase and the several challenges that characterize the Construction Industry from a cultural, economic, technological and sociological point of view, as found in [11], [17], [22] and [28]. Even if there are still many differences between the manufacturing and construction sectors, both are calling for new skills, performance standards, interoperability, training and an IT system that covers the whole lifecycle of complex products or buildings. Furthermore, the use of innovative technologies and methodologies in AEC industry is now steadily expanding, since it has reached a high level of awareness. As highlighted in [38] a mere integration of BIM and current PLM solutions based on discrete manufacturing, won't be able to satisfy the actual needs of the construction industry. BIM should inherit customized functionalities and features from PLM (mainly to enable collaboration and Facility Management) to become complete and effective in its scope or to evolve towards BLM [40]. Still, there is no agreement on the relationship between PLM and BLM. For some authors they are the same approach for lifecycle management, the first for manufacturing products, the second for construction products. Others refer to BLM as the sum or integration of BIM and PLM.

In section 6 the advantages deriving from the integration point out that: "Sharing knowledge and experiences in the implementation and use of PLM and BIM should be understood as an essential source of continuing improvement and innovation for both paradigms" as asserts [11], even if the reviewed articles underline much more the advantages of PLM application in AEC industry, at different degree of association. Another important benefit for AEC derives from PLM lessons learned. It emerges that it is necessary to extend, like current PLM applications for complex products, the BIM technologies across the entire lifecycle, especially along the facility management phase, gaining benefit from a "unifying platform that captures, integrates and shares the object-based information generated by BIM-based authoring, analysis, and simulation applications" [18]. In general, what seems to emerge is the unsatisfied need of managing the full lifecycle of a construction in a collaborative way and that BIM currently is not able to do it. Functionalities, features and best practices already mature PLMs in the complex product manufacturing, should be customized to the specific context of construction industry to effectively manipulate BIM models. 


\section{Conclusions and Further developments}

This study explores the relationship between BIM and PLM using a structured approach for the literature review through a qualitative analysis of the contents coming from selected papers. The scope is to provide a better understanding of the context, principles, technologies and practices underpinning a future technological implementation. The study is motivated by recent research on BIM and PLM and their relationship to lead in the extension of BIM through BLM.

The first important conclusion is, logically, that PLM seems to be considered more mature than BIM, whether as an approach, an IT system or a process. Most researches focused on the benefits of BIM inheriting PLM lesson learned, functionalities or even the full system.

Secondly, with respect to BIM many aspects of PLM have been analyzed so far, from collaboration to user management, knowledge and data management, configuration and change management. Gaps are discovered in the possibilities of learning from PLM configuration views, which is a key concept in the dedicated literature [33]. This concept is, in fact, already linked to BIM in [34] by citing Gielingh's stages [35]: "as required, as designed, as planned, as built as used as maintained, as demolished," as a way to model product lifecycle following a traditional linear lifecycle. Since it is still missing a concrete comparison about configuration management in BIM against PLM, it will be a focus on future research on this topic.

Thirdly, the authors this paper believe that there is a general confusion about the meaning of BIM and in plain language it has assumed lately broader implications or dimensions or "perspectives" (design, estimation, construction process, building lifecycle, performance and technology [41]).

As methods and IT solutions are born to satisfy specific needs, the reviewed papers converge to the construction industry's need of managing the full lifecycle of a building in a collaborative way on a centralized object oriented model. In order to fully satisfy this need, the AEC industry should reach the digitization level of Complex manufacturing industry. The evolution of concepts that led to the modern meaning of BIM as reported by [41], reminds us that BIM originated from Building Product Structure. The recent studies of [25] and [38], respectively pointing out that BIM is what PIM is to PLM and that product structure could be the "missing link in the BIM approach", bring us to consider the product structure as one of the most important features of BIM together with its being "object-oriented". Calling BLM the solution to the construction industry's need of managing the full lifecycle of a building in a collaborative way on a centralized object oriented model would better focus the aims of academic and software research. The same could happen if the common language would associate BIM more to its important feature of PIM.

Finally, from the study emerges that the relationship between BIM and PLM data model (or PIM) has not been investigated enough in the light of contemporary IT and many uncertainties are still observable in the use of BIM, PLM and BLM so the need for a standard terminology is highlighted. Therefore further research are needed on these topics. 


\section{References}

1. Saaksvuori A, Immonen A. Product Lifecycle Management: Springer-Verlag Berlin Heidelberg; 2002.

2. Stark J. Product Lifecyle Management : Springer International Publishing; 2015.

3. Corallo A, Latino ME, Lazoi M, Lettera S, Marra M, Verardi S. [2013]. Defining product lifecycle management: A journey across features, definitions, and concepts.. 2013.

4. Laiserin J. Comparing Pommes and Naranjas. [Online].; 2002 [cited 2017 Jenuary 14. Available from: HYPERLINK "http://www.laiserin.com/features/issue15/feature01.php" http://www.laiserin.com/features/issue15/feature01.php .

5. Eastman CM. An Outline of the Building Description System: Institute of Physical Planning, Carnegie-Mellon University; 1974.

6. Penttilä H. Describing the changes in architectural information technology to understand design complexity and free-form architectural expression. 2006.

7. Succar B. Building information modelling framework: A research and delivery foundation for industry stakeholders. 2009.

8. Azhar S. Building information modeling [BIM]: Trends, benefits, risks, and challenges for the AEC industry. 2011.

9. Bryman A, Bell E. Business Research Methods New York: Oxford University Press; 2007.

10. Jupp J.R. Cross industry learning: a comparative study of product lifecycle management and building information modelling. International Journal of Product Lifecycle Management 9.3 ,2016: p. 258-284

11. Jupp J.R., Nepal M. BIM and PLM: Comparing and Learning from Changes to Professional Practice Across Sectors. In 11th IFIP WG 5.1 International Conference, PLM 2014, July 79; 2014; Yokoama, Japan: Springer Berlin Heidelberg. p. 41-50.

12. Jupp JR, Singh V. Similar Concepts, Distinct Solutions, Common Problems:Learning from PLM and BIM. In The IFIP WG5.1 11th International Conference on Product Lifecycle Management - PLM14- 9th - 11th July; 2014; Yokoama, Japan.

13. Jupp J. Incomplete BIM Implementation: Exploring Challenges and the Role of Product Lifecycle Management Functions. IFIP Advances in Information and Communication Technology. 2013 July: p. 630-640.

14. Fadli F, Barki H, Shaat A, Mahdjoub L, Boguslawski P, Zverovich V. 3D capture techniques for BIM enabled LCM. In IFIP International Conference on Product Lifecycle Management; 2015; Doha, Qatar: Springer International Publishing. p. 183-192.

15. Popov V, Mikalauskas, Migilinskas D, Vainiūnas P. Complex usage of 4D information modelling concept for building design, estimation, sheduling and determination of effective variant. Ukio Technologinis ir Ekonominis. 2006: p. 91-98.

16. Migilinskasa, Popov V, Juocevicius, Ustinovichius L. The Benefits, Obstacles and Problems of Practical Bim Implementation. In 11th International Conference on Modern Building Materials, Structures and Techniques, MBMST 2013; 2013: Procedia Engineering.

17. Holzer D. Fostering the Link from PLM to ERP via BIM. The AEC Industry in Transition. In 11th IFIP WG 5.1 International Conference, PLM 2014, July 7-9; 2014; Yokoama, Japan. p. 75-82.

18. Aram S, Eastman C. Integration of PLM solutions and BIM systems for the AEC industry. In Proceedings of the 30th ISARC; 2013; Montreal, Canada. p. 1046-1055.

19. Luming, Singh. Comparing BIM in Construction with 3D Modeling in Shipbuilding Industries: Is the Grass Greener on the Other Side? In IFIP International Conference on Product Lifecycle Management ; 2015; Doha, Qatar: Springer International Publishing. p. 193-202.

20. Desprat C, Luga H, Jessel JP. Hybrid client-server and P2P network for web-based collaborative 3D design. In WSCG 2015 Conference on Computer Graphics, Visualization and Computer Vision; 2015; Plzen, Czech Republic. 
21. Heikkilä R, Hovila J, Ahola M, Nevala K, Schäfer T. Digital Product Process for Construction Product Industry. Proceedings of the 28th ISARC, Seoul, Korea 2011 p. 734-739.

22. Bricogne , Eynard B, Troussier N, Antaluca E, Ducellier G. Building lifecycle management: Overview of technology challenges and stakeholders. In Smart and Sustainable City [ICSSC 2011], IET International Conference on; 2011; Shanghai: IET. p. 1-5.

23. Oberoi S, Holzer D. Mechanical contractors: the key for supply chain integration in lifecycle BIM. Int. J. Product Lifecycle Management. 2016; 9[3].

24. Ran L, Singh V. Building information modelling-enabled best practices in AEC and takeaways for Finnish shipbuilding industry. Int. J. Product Lifecycle Management. 2016; 9[3].

25. Ramaji IJ, Memari AM. Product Architecture Model for Multistory Modular Buildings. Journal of Construction Engineering and Management. 2016; 142[10].

26. Bouguessa, Forgues D, Doré S. La complémentarité entre le Building Information Modeling [BIM] et le Product LifeCycle Management [PLM] en passant par le Lean Construction [LC]. In GSCE 2013 General Conference ; 2013; Montreal, Canada.

27. Nöldgen M, Harder J, Wassmann W. Closing the GAP in BIM - an Engineering Approach. In IABSE Symposium Report, IABSE Conference Geneva 2015: Structural Engineering: Providing Solutions to Global Challenges; 2015; Geneva: International Association for Bridge and Structural Engineering.

28. Reefman R.J.B., Van Nederveen GA. Knowledge management in an integrated design and engineering environment. In eWork and eBusiness in Architecture, Engineering and Construction: ECPPM 2012; 2012; Reykjavik, Iceland: CRC press.

29. Shin H.M., Lee H.M., Oh SJ, Chen J.H.. Analysis and Design of Reinforced Concrete Bridge Column Based on BIM. In The Twelfth East Asia-Pacific Conference on Structural Engineering and Construction; 2011; Hong Kong: Elsevier Ltd.

30. Foufou S., Fenves SJ, Bock C, Rachuri S, Sriram RD. A Core Product Model for PLM with an illustrative XLM implementation. In International Conference on Product Lifecycle Management. ; 2005.

31. Ahn S., Park M., Lee, Yang. Object oriented modelling of construction operations for schedule-cost integrated planning, based on BIM. In Proceedings of the International Conference on Computing in Civil and Building Engineering.; 2010; Nottingham.

32. Ibrahim M, Krawczyk R. The level of knowledge of CAD objects within the building information model. In Association for Computer-Aided Design in Architecture 2003 Conference; 2003. p. 172-177.

33. Eigner M, Fehrenz A. Managing the Product Configuration throughout the Lifecycle. In PLM11- 8th International Conference on Product Lifecycle Management ; 2011.

34. Eastman C.M. Building Product Models: Computer Environments, Supporting Design and Construction: CRC Press; 1999.

35. Gielingh W. General AEC reference model [GARM]. ISO TC184/SC4; 1988.

36. Vartiainen P. On the principles of comparative evaluation. 2002; Vol 8[3]: p. 359-371.

37. Stark J. Product Lifecycle Management: Springer International Publishing; 2015.

38. Boton C, Rivest L, Forgues D, Jupp J. Comparing PLM and BIM from the product structure standpoint. In IFIP International Conference on Product Lifecycle Management. Springer, Cham. 2016. p. 443-453.

39. Den Otter A, Pels H J, Iliescu I. BIM versus PLM: Risks and benefits. 2011.

40. Kubler S, Buda A, Robert J, Främling K. Building Lifecycle Management System for Enhanced Closed Loop Collaboration. In 13th IFIP International Conference on Product Lifecycle Management. Springer, 2016.

41. Latiffi, A. A., Brahim, J., \& Fathi, M. S. The development of Building Information Modeling (BIM) definition. Applied Mechanics and Materials, 567, 2014, p 625-630. 